\title{
Activated Protein C in Cutaneous Wound Healing: From Bench to Bedside
}

\author{
Ruilong Zhao ${ }^{1}$, Haiyan Lin ${ }^{1}$, Lara Bereza-Malcolm ${ }^{1}$, Elizabeth Clarke ${ }^{2}$, \\ Christopher John Jackson ${ }^{1}(\mathbb{D})$ and Meilang Xue ${ }^{1, * \mathbb{C}}$ \\ 1 Sutton Arthritis Research Laboratory, Kolling Institute of Medical Research, Sydney Medical School, \\ Northern Clinical School, University of Sydney, Sydney, NSW 2065, Australia; \\ rzha9073@uni.sydney.edu.au (R.Z.); haiyan.lin@sydney.edu.au (H.L.); \\ lara.bereza-malcolm@sydney.edu.au (L.B.-M.); chris.jackson@sydney.edu.au (C.J.) \\ 2 Murray Maxwell Biomechanics Laboratory, Kolling Institute of Medical Research, Sydney Medical School, \\ Northern Clinical School, University of Sydney, Sydney, NSW 2065, Australia; \\ elizabeth.clarke@sydney.edu.au \\ * Correspondence: meilang.xue@sydney.edu.au; Tel.: +61-2-99264816
}

Received: 24 January 2019; Accepted: 16 February 2019; Published: 19 February 2019

\begin{abstract}
Independent of its well-known anticoagulation effects, activated protein C (APC) exhibits pleiotropic cytoprotective properties. These include anti-inflammatory actions, anti-apoptosis, and endothelial and epithelial barrier stabilisation. Such beneficial effects have made APC an attractive target of research in a plethora of physiological and pathophysiological processes. Of note, the past decade or so has seen the emergence of its roles in cutaneous wound healing-a complex process involving inflammation, proliferation and remodelling. This review will highlight APC's functions and mechanisms, and detail its pre-clinical and clinical studies on cutaneous wound healing.
\end{abstract}

Keywords: activated protein C; wound healing; cytoprotection; cell culture; animal models; clinical trials

\section{Background}

\subsection{Production and Activation}

Protein C (PC) was first noted to play a role in anticoagulation in 1960 [1], but was not isolated until 1976, when it was determined to be a vitamin K-dependent zymogen [2]. Its synthesis begins predominantly in liver cells from the human PROC gene on chromosome 2 (2q13-14) [3]. There it is translated from nine exons to a single chain precursor molecule, composed of a signal peptide and a propeptide [4]. Key post-translational modifications include $\beta$-hydroxylation at Asp71; N-linked glycosylation at residues 97, 248, 313 and 329; and $\gamma$-carboxylation of nine glutamic acid residues to form the Gla domain of the amino terminus [3]. Upon secretion, the precursor is cleaved to produce one light chain $(21 \mathrm{kDa})$ and one heavy chain $(41 \mathrm{kDa})$ connected by a disulfide bond, creating the mature heterodimer that is PC [4]. PC consists of several moieties: a Gla domain, an aromatic segment and two epidermal growth factor (EGF)-like domains within the light chain, and a serine protease domain and activation peptide within the heavy chain [5]. It is primarily in this form that PC circulates as a zymogen in the plasma at $70 \mathrm{nM}$, whereas its activated form is present at $40 \mathrm{pM}$ [6]. Activated protein $\mathrm{C}$ (APC) is generated by thrombin cleavage, removing the activation peptide. This process occurs primarily on the endothelial cell surface, and is strongly promoted by endothelial protein $\mathrm{C}$ receptor (EPCR) and the formation of a thrombin-thrombomodulin complex [7,8]. Human epidermal keratinocytes have also been found to express PC, EPCR, thrombomodulin, and other related receptors 
(described below) involved in PC's actions and activation [9-12]. Figure 1 provides a schematic representation of this activation on endothelial and epithelial cells.

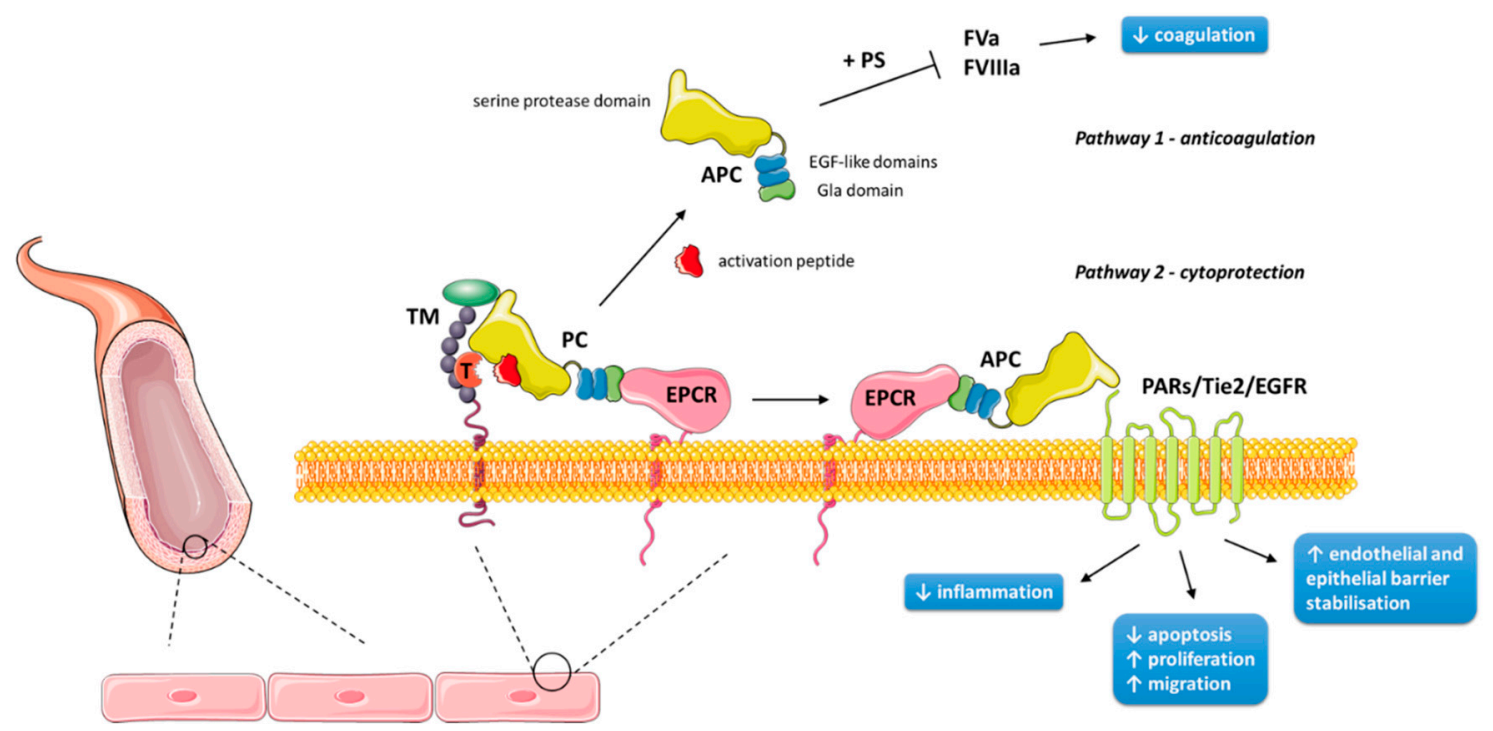

Figure 1. Mechanism of protein $C$ activation and actions on the surface of human endothelial cells. Protein C (PC) is bound to an endothelial protein C receptor (EPCR) on the surface of endothelial cells, where it is activated by thrombin (complexed with thrombomodulin) cleavage of its activation peptide. Activated protein C (APC) is then either released, where it participates in negative feedback of the coagulation cascade (pathway 1), or presented to cleave PARs/Tie2/EGFR in order to exert its cytoprotective effects (pathway 2). Pathway 2 also occurs on the surface of keratinocytes. EGFR: endothelial growth factor receptor; FVa: activated factor V; FVIIIa: activated factor VIII; PAR: protease-activated receptor; PS: protein S; T: thrombin; TM: thrombomodulin. Figure was produced using Servier Medical Art (https:/ / smart.servier.com).

APC's pleiotropic activities make it an attractive candidate for potential roles in the treatment of complex disorders, including sepsis [13], ischaemic stroke [14], and chronic wounds [15]. APC has two main classes of functions: anticoagulation and cytoprotection.

\subsection{Anticoagulation Pathway}

APC performs its anticoagulant effects along with cofactors, including factor V, high density lipoprotein, anionic phospholipids, glycosphingolipids, and in particular, protein $\mathrm{S}$ - the Gla domain mediating the cofactors' $\mathrm{Ca}^{2+}$-dependent interactions [16,17]. On the surface of negatively charged membrane surfaces, such as platelets, APC irreversibly proteolytically cleaves coagulation factors Va and VIIIa (Figure 1), thus inactivating both intrinsic and extrinsic coagulation cascades $[18,19]$. An insight into the significance of APC as an anticoagulant is elucidated from the fatal consequences of its homozygous deficiency, which causes neonatal purpura fulminans and its associated skin necrosis; its significance can also be seen from the increased risk of venous thrombosis with APC's heterozygous deficiency [20].

\subsection{Cytoprotective Pathways}

APC has several cytoprotective properties, which are independent from its anticoagulation pathway [21]. These include anti-inflammatory actions, anti-apoptosis, and endothelial and epithelial barrier stabilisation [3]. Many such properties require EPCR and protease-activated receptor (PAR)-1, a G protein-coupled receptor [22]. EPCR, which itself is anti-inflammatory, binds APC and presents APC to the cleavage site on PAR-1 [23] (Figure 1). Interestingly, PAR-1 is primarily a thrombin receptor; thrombin cleaves PAR-1 much more efficiently than APC, and the thrombin-triggered PAR-1 signalling 
pathway is pro-inflammatory and endothelial barrier-disruptive [24]. This paradox may be explained by the co-localisation of EPCR and PAR-1 on caveolin-1-enriched membrane rafts or caveolae, boosting the efficiency of PAR-1 activation by APC within these microdomains $[25,26]$, as well as by PAR-1 being shown to be a biased receptor. Thrombin cleaves and activates PAR-1 at the canonical Arg 41 site, whereas APC cleaves PAR-1 predominantly at Arg46 in the presence of EPCR $[27,28]$. The APC-cleaved peptide comprised of PAR-1 residues 47-66 (TR47) has been shown to mimic APC's cytoprotective properties in vitro and in vivo [27].

The anti-inflammatory effects of APC are primarily associated with actions on endothelial cells and leukocytes. APC limits tissue damage through the suppression of the nuclear factor (NF)- $\mathrm{KB}$ pathway in endothelial cells. APC also inhibits inflammatory mediators such as tumour necrosis factor (TNF)- $\alpha$, and down-regulates vascular adhesion molecules, such as intercellular adhesion molecule-1, reducing leukocyte adhesion and infiltration of tissues [29,30]. In addition, APC maintains endothelial barrier function and reduces chemotaxis [21]. Similarly, APC also diminishes leukocyte release of cytokines, such as macrophage inflammatory protein- $1 \alpha$, monocyte chemoattractant protein-1 (MCP-1), and TNF- $\alpha$, to potentially attenuate systemic inflammatory responses [31,32]. In rheumatoid synovial fibroblasts and monocytes, APC further suppresses NF- $K B$ activation and TNF- $\alpha$ production, while upregulating anti-inflammatory matrix metalloprotein (MMP)-2 and downregulating pro-inflammatory MMP-9 [33]. Moreover, a recent study has further indicated that APC suppresses nucleotide-binding oligomerization domain-like receptor protein 3 (NLRP3) inflammasome activation via PAR-1 in mice macrophages and cardiac and renal tissue [34]. These data identify APC as a viable and critical target of anti-inflammatory therapy.

APC up-regulates around 20 genes engaged in anti-inflammatory and anti-apoptotic pathways, and down-regulates around 20 genes in pro-inflammatory and pro-apoptotic pathways [21]. While many of these mechanisms are not well understood, it is believed that they at least partly involve the inhibition of transcription factor activity. Of note, Joyce et al. [35] have shown that APC suppresses expression of $p 50$ and $p 52 \mathrm{NF-KB}$ subunits, which is implicated in cytokine signalling and TNF- $\alpha$-dependent inflammatory pathways. Furthermore, APC augments anti-apoptotic gene products related to Bcl-2, and suppresses pro-apoptotic $p 53$ and Bax expression [36,37].

APC has demonstrated inhibition of apoptosis in a number of cells. Its activity is dependent partly on modulation of gene expression, and partly on the direct inhibition of apoptotic mediators, such as caspases-3 and -8 [21,35]. When brain endothelial cells are under hypoxic stress, APC reduces pro-apoptotic p53 and Bax, but maintains levels of protective Bcl-2, thereby minimising stimulation of the intrinsic apoptotic pathway [37]. In human skin keratinocytes, APC suppresses apoptosis by preventing the activation of caspase-3 [38]. On the flipside, APC stimulates angiogenesis, and both the proliferation and migration of human keratinocytes [38,39].

Endothelial cells serve as a barrier between the intravascular compartment and the interstitium, and breakdown of this barrier is a key pathogenic factor in inflammation. APC's barrier protective mechanisms act through EPCR-dependent PAR-1 activation in two main ways. Firstly, APC stimulates sphingosine kinase-1 to form sphingosine-1-phosphate (S1P) from sphingosine [40]. When activated by S1P, sphingosine-1-phosphate receptor 1 (S1P1) mediates second messengers Rac (protective) and Rho (destabilising) to stabilise the cellular cytoskeleton, reducing endothelial permeability [41]. Secondly, APC employs the angiopoietin/Tie2 axis to up-regulate zona occludens- 1 and smooth muscle cell migration, significantly reducing human umbilical vein endothelial cell (HUVEC) permeability [42]. Additionally, PC makes direct contributions to vascular membrane formation via the stimulation of type IV collagen and MMP-2 [43]. Finally, through similar pathways, APC has also been shown to promote barrier functions of the skin, as well as the intestinal and alveolar epidermis [12,44,45].

In addition to EPCR and PAR-1, studies have revealed other key receptors that play a major role in APC-mediated signalling of different cells, such as S1P1, several integrins, PAR-2, PAR-3, apolipoprotein E receptor 2 (ApoER2), glycoprotein Ib, CD11b, Tie2, and EGF receptor (EGFR) [30,46]. For example, Xue et al. [12] show that when activated on confluent keratinocytes, PAR-1's coupled G 
protein transactivates EGFR, which further activates the Tie2 receptor; this action enhances PI3K/Akt and inhibits ERK to stimulate junctional complexes and reduce keratinocyte permeability. Similarly, APC stabilises the endothelial barrier by activating PAR-1 and Tie2 while bound to EPCR [42], or by binding directly to Tie2 [47]. APC can also act independently of EPCR by binding to integrin CD11b/CD18 on macrophages to facilitate anti-inflammatory actions [48], or by inhibiting apoptosis in podocytes through the proteolytic activation of PAR-3 [49]. APC-ameliorated nephropathy is achieved by PAR-1 and PAR-3 in podocytes [50]. In human lymphocytes, APC stimulates phosphorylation of EGFR to arrest the lymphocytes' directed migration [51]. In MDA-MB-231 cancer cells, APC requires three receptors-EPCR, PAR-1, and EGFR - to promote cell invasion [52]. APC suppresses human osteoclast differentiation mainly by inhibiting the formation of multinucleated cells via EPCR, PAR-1, S1P1, and ApoER2 [53]. Finally, the wound promoting effects of APC on mouse full-thickness wounds depends on PAR-2 activity [54], and APC signals via PAR-2 and PAR-3 to expand regulator T-cells, mitigating graft-versus-host disease in mice [55].

\section{Active Protein $\mathrm{C}$ in Wound Healing}

\subsection{Cell Culture}

Keratinocytes, endothelial cells, and fibroblasts are the major cell types in the skin, and play critical roles in wound healing. Keratinocytes and endothelial cells form important functional barriers, and all three cell types express a plethora of cytokines and growth factors involved in wound healing. APC acts on these major cellular components to ensure their appropriate functions in cutaneous wound healing (Figure 2).

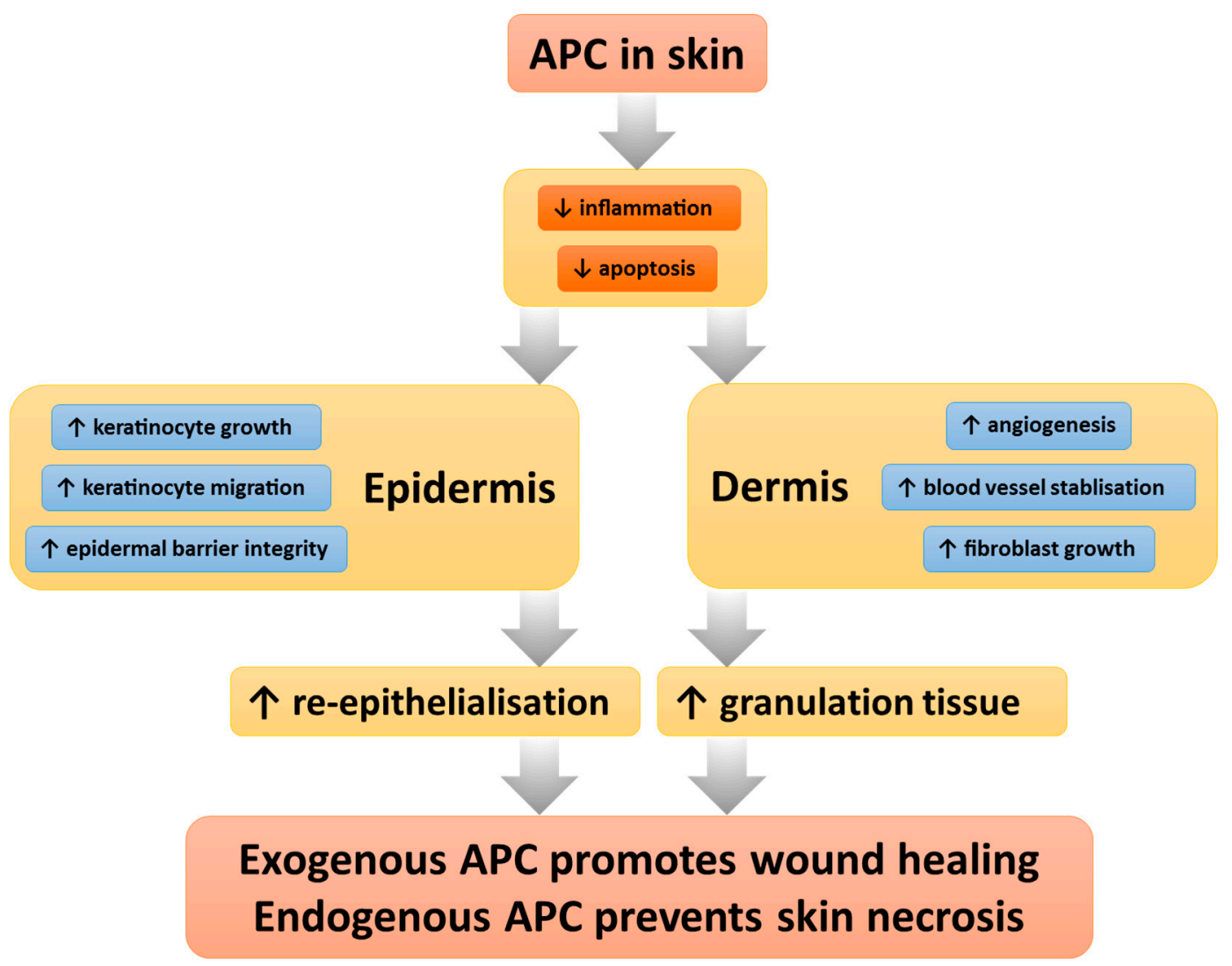

Figure 2. APC exerts its protective actions on major cellular components of the skin to ensure normal homeostasis. 
Keratinocytes represent the major cellular component of the epidermis, and are responsible for maintaining structure and homeostasis of the epidermal barrier [56]. Once thought to be synthesised exclusively by the liver and endothelial cells, more recent evidence shows that keratinocytes also express PC mRNA and protein, and exhibit APC activity [9]. In cultured human keratinocytes, APC promotes proliferation, while gene silencing of PC increases apoptosis three-fold [9]. Importantly for wound healing, APC dose-dependently stimulates keratinocyte migration, possibly by its stimulation and activation of MMP-2 [38], which also has anti-inflammatory properties. MMP-2 degrades collagen present in the basement membrane, which is crucial in the invasive processes of re-epithelialisation and in angiogenesis [57]. Finally, in keratinocyte monolayers, APC decreases permeability to enhance barrier function by up-regulating tight junction proteins and redistributing them to cell-cell contacts, via the signaling pathway described above [12].

Endothelial migration and proliferation are vital in generating new vessels during the proliferative phase of healing. APC up-regulates gene and protein expression of angiogenic factors in several cultured human cells [57]. In particular, APC enhances MMP-2 and MCP-1 in fibroblasts and HUVECs, and vascular endothelial growth factor (VEGF) in keratinocytes and fibroblasts $[58,59]$. Using a chick embryo chorioallantoic membrane assay, Jackson et al. [58] showed that APC stimulates massive formation of fine capillary vessels, as well as a marked proliferation of the ectodermal epithelium. Similar to keratinocytes, APC induces endothelial cell proliferation, tube-like structure formation, and migration in vitro [39,59]. As mentioned previously, APC also maintains the essential endothelial barrier function.

Smooth muscle cells have been shown to express functionally active EPCR, potentially contributing to the formation of mature blood vessels [60]. In dermal fibroblasts, which help lay down the provisional wound matrix and guide wound contraction and maturation, APC increases MMP-2, VEGF and MCP-1 in human fibroblasts, although the mechanisms are not clearly understood [58].

\subsection{Animal Models}

The findings on APC's anti-inflammatory and cytoprotective properties prompted researchers to investigate its action on cutaneous wound healing in experimental animals (Table 1). Following their in vitro work, Uchiba et al. [39] demonstrated that APC induces a corneal angiogenic response in mice comparable to that of VEGF, the most potent angiogenic mediator currently known. Endothelial nitric oxide synthase (eNOS) was essential in APC's angiogenic pathway, as angiogenesis was not induced in eNOS knockout mice. Jackson et al. [58] showed that a single topical application of APC enhanced healing in full-thickness excisional wounds when compared to the control in both normal and diabetic rats, with no adverse side effects like toxicity or bleeding observed. APC-treated wounds had more blood vessels on day 7, and lower neutrophil infiltration on days 4 and 7; however, the addition of a broad spectrum MMP inhibitor, GM6001, abolished APC's actions. Their data suggest that APC's multifaceted promotion of cutaneous wound healing involves at least the stimulation of angiogenesis and inhibition of inflammation. Julovi et al. [54] confirmed these results in C57BL/6J mice (Figure 3), and further used PAR-1 and PAR-2 knockout mice to reveal that PAR-2, but not PAR-1, was necessary for APC to accelerate wound healing; in addition, they confirmed that inhibition of phosphorylated p38 via APC's cleavage of PAR-2 boosted healing in wild-type mice. Three studies further examined the cutaneous effects of systemic APC - one on flap necrosis and two on burn injuries. In dorsal cutaneous flaps on rats, systemic APC significantly improved flap survival compared to controls, corresponding to increased blood vessel density and muscle cell viability, with fewer inflammatory cells; PCR revealed the modulation of several genes associated with these outcomes [61]. The two burn models appeared to show conflicting results. Nisanci et al. [62] utilised a "comb burn" model with eight $1 \mathrm{~cm} \times 2 \mathrm{~cm}$ areas per rat injured by a heated brass block held for 20 seconds, showing positive results for APC treatment. However, Meyerholz et al. [63] injured ten $2 \mathrm{~cm} \times 2 \mathrm{~cm}$ areas per rat that ranged from 1 to 14 seconds of heated aluminium branding, revealing deleterious APC treatment effects. The former clearly created smaller but deeper burns with no fluid resuscitation following 
injury, while the latter had larger and more superficial burns with fluid resuscitation via femoral vein cannulation. It may be that the larger, more superficial burns (most of which were branded with contact times of less than $10 \mathrm{~s}$ were not severe enough and were too well resuscitated to show the benefit-a landmark trial had shown that APC's benefit in severe sepsis was limited to those with Acute Physiologic Assessment and Chronic Health Evaluation (APACHE) II scores of 25 or higher [64]. Furthermore, Nisanci et al. measured perfusion on day 3, compared to Meyerholz et al. who measured just $5 \mathrm{~h}$ after injury. However, in the "comb burn" model, APC only increased blood flow in the zone of stasis, and not the actual burned area (taken to be the zone of coagulation), which is potentially congruent with the miniscule perfusion differences in just the more severely burned areas of the latter study. Perhaps systemic APC treatment has a paradoxically negative effect on burn injuries in the acute phase, especially in less severe injuries; however, this effect reverses to become advantageous in the subacute phase. A possible culprit for this difference early on may be found in a syndrome called acute traumatic coagulopathy, where endothelial PC activation plays a central role-exogenous APC exacerbates any rapid anticoagulation and fibrinolysis following severe trauma, which can worsen organ-specific and systemic complications [65]. In large animals, APC has had no effect on macroscopic healing metrics for equine distal limb wounds, but has demonstrated enhanced epithelialisation and angiogenesis histologically [61]. This disparity with small animal studies may be explained by their indirect method of APC application (gauze pad soaked in APC solution); while this method was more practical in horses, optimal local APC may not have been achieved in their wounds. However, recent data from our group in a porcine wound model did show increased healing through a combined topical and subcutaneous APC treatment regime, with no bleeding side effects. Together, these results indicate that APC's impacts are evident in not only cell culture but also animal wounds, where it is both effective and safe to use.

While in vitro and in vivo investigations can provide valuable insight into specific pathways and a focused approach to the pathophysiology underlying human chronic wounds [66], the lack of concordance with human skin has been cited as a major impediment into translational research. Mice and rats are loose-skinned, and their open wounds heal mostly by contraction-a stark contrast to the lower limbs of humans, a common site for chronic wounds [67-69]. However, the unpublished porcine study shows promising results in an animal with 78\% concordance rate to human wound healing [70]. Unfortunately, another difficulty presents itself in reproducing comorbid and causative conditions, such as neuropathy, chronic debility or vascular insufficiency in animals, and there is a paucity of truly aged animals to provide precise models of chronic wounds [71]. Nonetheless, the positive results described above have encouraged researchers to pursue small clinical trials in human chronic wounds. 
Table 1. APC in animal wound models.

\begin{tabular}{|c|c|c|c|c|c|c|}
\hline Study & Animal & Wound Model & Dosage & Mode of Administration & Duration of Administration & Effects \\
\hline Uchiba et al. [39] & $\begin{array}{l}\text { Male eight-week-old C57BL/6 } \\
\text { mice and eNOS KO mice }\end{array}$ & Corneal angiogenesis & Not reported & $\begin{array}{c}\text { Slow-release pellets implanted } \\
\text { in corneal stroma }\end{array}$ & 6 days & $\uparrow$ corneal angiogenic response \\
\hline Jackson et al. [58] & $\begin{array}{l}\text { Normal and diabetic } \\
\text { Sprague-Dawley rats }\end{array}$ & $\begin{array}{l}\text { Full-thickness excisional } \\
\text { wounds }\end{array}$ & $\begin{array}{c}5 \mu \mathrm{g}, 20 \mu \mathrm{g} \text { and } \\
40 \mu \mathrm{g} / \text { wound }\end{array}$ & Topical & Single dose & $\begin{array}{c}\uparrow \text { healing in both normal and } \\
\text { diabetic rats } \\
\downarrow \text { inflammation } \\
\uparrow \text { angiogenesis }\end{array}$ \\
\hline Bezuhly et al. [36] & Male Sprague-Dawley rats & $\begin{array}{l}\text { Cranially based dorsal } \\
\text { cutaneous flap }\end{array}$ & $25 \mu \mathrm{g} / \mathrm{kg}$ & Tail vein injection & $\begin{array}{l}3 \text { injections (early pre-, late } \\
\text { pre-, or post-operatively; } 3 \mathrm{~h} \\
\text { post-operatively; and } 24 \mathrm{~h} \\
\text { post-operatively) }\end{array}$ & $\begin{array}{c}\uparrow \text { ischaemic flap survival } \\
\downarrow \text { inflammation } \\
\uparrow \text { angiogenesis } \\
\uparrow \text { muscle cell viability } \\
\downarrow \text { mRNA of ICAM- } 1 \text { and TNF- } \alpha \\
\uparrow \text { mRNA of EGR- } 1 \text {, VEGF, and Bcl- } 2\end{array}$ \\
\hline Nisanci et al. [62] & Male Sprague-Dawley rats & Burn injury & $100 \mu \mathrm{g} / \mathrm{kg}$ & Tail vein injection & $\begin{array}{l}\text { One injection two hours after } \\
\text { burn injury }\end{array}$ & $\begin{array}{c}\uparrow \text { tissue perfusion } \\
\downarrow \\
\downarrow \text { area of skin necrosis in zone of } \\
\text { stasis }\end{array}$ \\
\hline Meyerholz et al. [63] & Male Sprague-Dawley rats & Burn injury & $24 \mu \mathrm{g} / \mathrm{kg} / \mathrm{h}$ & $\begin{array}{l}\text { Microinfusion pump through } \\
\text { proximal femoral vein }\end{array}$ & $\begin{array}{l}5 \mathrm{~h} \text { from burn creation to } \\
\text { animal sacrifice }\end{array}$ & $\begin{array}{l}\downarrow \text { tissue perfusion } \\
\uparrow \text { burn depth } \\
\uparrow \text { inflammation } \\
\downarrow \text { apoptosis }\end{array}$ \\
\hline Julovi et al. [54] & $\begin{array}{l}\text { Male C57BL/6J WT, and PAR-1 } \\
\text { and PAR-2 KO mice }\end{array}$ & $\begin{array}{l}\text { Full-thickness excisional } \\
\text { wounds }\end{array}$ & $10 \mu \mathrm{g} /$ wound & Topical & Once per day for 3 days & $\begin{array}{c}\text { healing in WT and PAR-1 KO mice } \\
\downarrow \text { inflammation } \\
\quad \uparrow \text { angiogenesis } \\
\uparrow \text { re-epithelialisation. } \\
\text { Negligible effect in PAR-2 KO mice }\end{array}$ \\
\hline Bischofberger et al. [61] & Standardbred geldings & $\begin{array}{l}\text { Full-thickness excisional } \\
\text { wounds }\end{array}$ & $190 \mu \mathrm{g} /$ wound & $\begin{array}{l}\text { APC solution-soaked gauze } \\
\text { pad }\end{array}$ & $\begin{array}{l}4 \mathrm{~h} \text { applications on days } 1,3,6 \\
\text { and } 9\end{array}$ & $\begin{array}{c}\text { No effect on wound size, rate of } \\
\text { healing, or overall time to heal } \\
\uparrow \text { angiogenesis } \\
\uparrow \text { re-epithelialisation }\end{array}$ \\
\hline
\end{tabular}

protease-activated receptor; mRNA: messenger ribonucleic acid; VEGF: vascular endothelial growth factor; WT: wild-type; $\uparrow=$ increased; $\uparrow=$ decreased. 
A

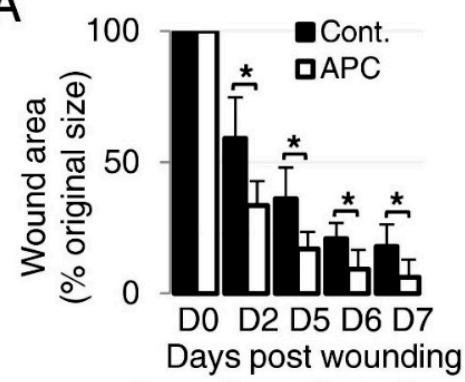

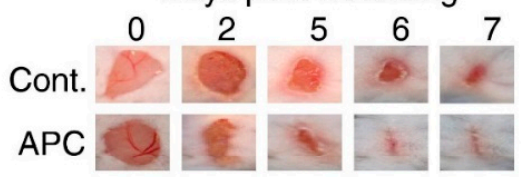

D

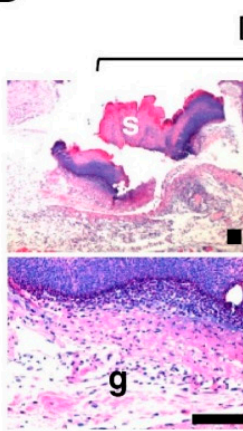

Cont.
D3

D3

(1)

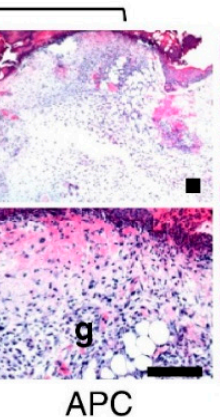

B

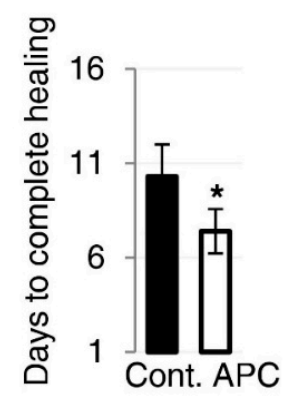

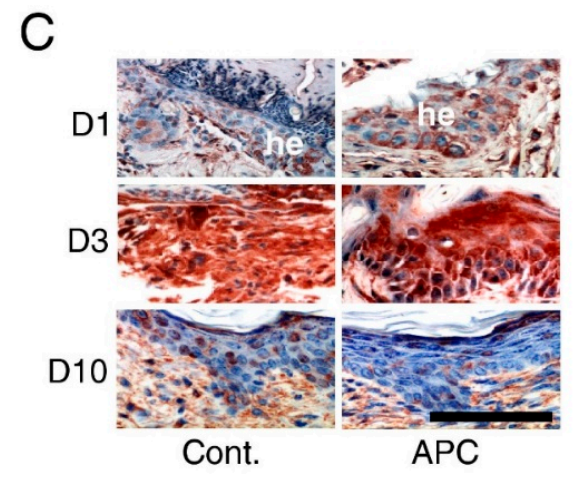

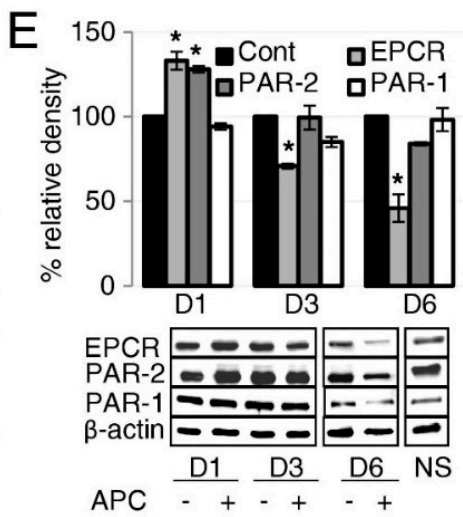

Figure 3. APC accelerates wound healing in wild-type (WT) mice. (A) and (B) Full-thickness 6-mm diameter wounds were made and treated topically with $20 \mu \mathrm{L}$ of phosphate-buffered saline or APC (10 $\mu \mathrm{g}$ ) once a day for three consecutive days. (A) Representative photographs of skin wounds on days after APC treatment. The percentage of wound area/initial area was calculated from tracing the wounds, measured with Visitrak. Values are mean $\pm \mathrm{SD} ; n=10$ wounds. ${ }^{*} p<0.05$ by paired $t$-test. (B) Time to complete wound closure. Values are mean $\pm \mathrm{SD} ; n=10$ wounds. ${ }^{*} p<0.05$ by $t$-test. (C) Expression of PAR-2 by immunohistochemistry on wounded skin in WT mice (he: hyperproliferative epithelium). Scale bar $=100 \mu \mathrm{m}$. (D) Hematoxylin and eosin -stained paraffin sections from day 3 and day 10 wounds from WT mice. Arrows indicate the leading edge of the migrating epithelial tongue (e: epithelium; g: granulation tissue; he: hyperproliferative epithelium; s: scab). Scale bar $=100 \mu \mathrm{m}$. (E) Expression of EPCR, PAR-1, and PAR-2 detected by immunoblotting from homogenate supernatants of wounded skin (NS: normal skin). The band intensity of the protein was normalized with $\beta$-actin, and each control was defined as $100 \%$. Values are mean $\pm \mathrm{SD} ; n=3$. ${ }^{*} p<0.05$ versus each control on each day by paired t-test. Copyright (C) 2011 American Society for Investigative Pathology. Published by Elsevier Inc. All rights reserved. Reproduced with permission. License number 4526191003342.

\subsection{Clinical Trials}

In addition to the animal experiments, APC's associations with human non-healing wounds have been reported in six clinical studies (Table 2). Similar to the majority of the animal studies, APC was applied topically in study participants to minimise potential systemic side effects, and the macroscopic endpoints used also included time to complete healing and wound area reduction. With the exception of one study where biopsies were taken, no other clinical studies assessed wound healing metrics microscopically. Firstly, Whitmont et al. [72] conducted an open-label pilot study on four patients with non-healing leg ulcers of various causes for four months or more despite standard wound care, who received weekly topical applications of APC for four weeks. The treatment was well-tolerated, with no significant side effects or complications, and all four patients showed a rapid positive response that was maintained during a four-month follow-up period; more than $80 \%$ reduction 
in wound size was observed overall after eight weeks. The same group later showed that diabetic patients with lower leg ulcers have significantly reduced levels of circulating PC compared to diabetic patients without ulcers, when corrected for age and matched for gender and type of diabetes [73]. The authors proposed that lower plasma PC levels may predispose ulceration in diabetic patients. Wijewardena et al. [74] piloted another study, where four patients with recalcitrant orthopaedic wounds were treated with APC in conjunction with topical negative pressure (TNP). Within one week, all cases showed a clear reduction in wound size and depth, with remarkable increases in granulation tissue; the treated wounds either closed completely or had sufficient granulation tissue to allow for split-thickness skin grafting. APC treatment was well-tolerated and no osteomyelitis was seen in the long-term follow-up. These promising early results necessitated a randomised, placebo-controlled, double-blind trial to rigorously determine the efficacy of APC. Whitmont et al. [75] produced such a study involving 12 diabetic patients with lower leg ulcers, randomly assigned to receive topical APC or physiological saline. They reported that APC significantly reduced the wound areas at 20 weeks, with three APC-treated wounds completely healing compared to one saline-treated wound. Wound edge skin biopsies showed that APC treatment decreased inflammatory cell infiltration and increased vascular proliferation, similar to the histological results of the small animal studies. They also reported reduced patient stress scores following APC treatment, as assessed by the Cardiff Wound Impact Questionnaire, demonstrating improved quality of life. Two further case series have been published, each involving two patients, determining the efficacy of APC for ulcers caused by pyoderma gangrenosum in one study, and severe chronic pressure sores in the other [76,77]. APC was injected subcutaneously and applied topically combined with TNP, respectively; both methods led to clinical improvements and reductions in wound size (Figure 4). Although these studies conducted so far have been small, such promising results in refractory wounds, even those of dissimilar aetiologies, paint an encouraging picture of APC as a safe wound-healing agent, and provide supporting evidence for future larger clinical trials. Recently, a larger observational study in burn patients has been completed by our group, where it was found that plasma PC levels rose over time with patient recovery, and that low day 0 plasma PC levels predicted for worse clinical outcomes. The known effects of APC in human skin are summarised in Figure 5.

Although the various human chronic ulcers differed in pathophysiology to the animal acute wounds, both clinical and preclinical studies found that APC exerted effects in the epidermis, where it promoted re-epithelialisation, as well as in the dermis, where it encouraged granulation tissue formation while reducing inflammatory infiltrate. The consistent positive results add weight to the rationale for APC's role in wound healing, originally formed through in vitro experiments (Figure 2).

By suppressing inflammation, inducing angiogenesis, and re-epithelialisation, APC is also likely to minimise scar formation, in addition to hastening wound healing. The obvious benefit is for burn victims and those susceptible to keloid scarring [30]. However, the application of APC may also hold great potential for any surgical wound, where enhancements in healing times and wound aesthetics would constitute improved clinical outcomes and patient satisfaction. 
Table 2. APC in Clinical Trials.

\begin{tabular}{|c|c|c|c|c|c|c|}
\hline Study & Study Type & Wound Aetiology & Dosage & Mode of Administration & Duration of Administration & Effects \\
\hline Whitmont et al. [72] & Open-label pilot study & $\begin{array}{l}\text { Venous }(n=1) \text {, arteriovenous }(n=1), \\
\text { diabetic/neuropathic }(n=1) \text {, diabetic }(n=1)\end{array}$ & $200 \mu \mathrm{g} / \mathrm{mL}$ solution & $\begin{array}{l}\text { Topical: APC solution was } \\
\text { injected into wound space until } \\
\text { level with skin surface (max. } \\
1.6 \mathrm{~mL} \text { was sufficient) }\end{array}$ & $\begin{array}{l}\text { Once per week for four } \\
\text { weeks }\end{array}$ & $\begin{array}{l}\text { All four patients showed steady } \\
\text { progress in healing over an } \\
\text { eight-week treatment/follow-up } \\
\text { period, with a pooled reduction of } \\
80 \% \text { in wound size }\end{array}$ \\
\hline Wijewardena et al. [74] & Open-label pilot study & Recalcitrant orthopaedic wounds $(n=4)$ & $\begin{array}{l}400 \mu \mathrm{g} / \mathrm{mL} \text { solution at } \\
\text { roughly } 1 \mathrm{~mL} / \mathrm{cm}^{2}\end{array}$ & $\begin{array}{l}\text { Topical and subcutaneously } \\
\text { (max. } 3 \mathrm{~mL})\end{array}$ & $\begin{array}{c}\text { Twice per week until } \\
\text { complete wound closure or } \\
\text { sufficient improvement for } \\
\text { surgical intervention }\end{array}$ & $\begin{array}{l}\text { Two wounds healed } \\
\text { completely—one allowed for } \\
\text { split-thickness skin graft, one } \\
\text { allowed for primary closure }\end{array}$ \\
\hline Whitmont et al. [73] & Case-control & $\begin{array}{l}\text { Neuropathic }(n=14) \text {, ischaemic }(n=10), \\
\text { mixed neuropathic ischaemic }(n=11), \\
\text { venous }(n=1) \text {, all in diabetic patients }\end{array}$ & $\mathrm{N} / \mathrm{A}$ & $\mathrm{N} / \mathrm{A}$ & N/A & $\begin{array}{l}\text { Ulceration in diabetic patients is } \\
\text { correlated to lower plasma PC } \\
\text { levels }\end{array}$ \\
\hline Kapila et al. [76] & Open-label pilot study. & Pyoderma gangrenosum $(n=2)$. & $400 \mu \mathrm{g}$ in $1 \mathrm{~mL}$ solution. & Subcutaneously. & Once per week for six weeks. & $\begin{array}{l}\text { APC reduced wound area by } 78.9 \% \\
\text { and } 70.0 \% \text { in the two patients, } \\
\text { respectively, and pain scores by } \\
100 \% \text { in both. }\end{array}$ \\
\hline Wijewardena et al. [77] & Open-label pilot study. & Pressure ulcers $(n=2)$ & $\begin{array}{l}400 \mu \mathrm{g} / \mathrm{mL} \text { and } 200 \mu \mathrm{g} / \mathrm{mL} \\
\text { solutions, respectively. }\end{array}$ & $\begin{array}{l}\text { Topical: APC solution was } \\
\text { injected into wound space until } \\
\text { level with skin surface (max. } 8 \\
\mathrm{~mL} \text { of the } 200 \mu \mathrm{g} / \mathrm{mL} \text { solution). }\end{array}$ & $\begin{array}{l}\text { Twice per week for } 24 \text { and } 64 \\
\text { days, respectively. }\end{array}$ & $\begin{array}{l}\text { Both wounds healed completely by } \\
\text { day } 35 \text { and } 80 \text { respectively. }\end{array}$ \\
\hline Whitmont et al. [75] & Randomised controlled trial. & $\begin{array}{l}\text { Control: neuropathic }(n=4) \text {, venous }(n=2) \text {. } \\
\text { APC: neuropathic }(n=3) \text {, venous }(n=3) \text {. }\end{array}$ & $400 \mu \mathrm{g} / \mathrm{mL}$ solution. & $\begin{array}{l}\text { Topical, APC solution or saline } \\
\text { control was injected into } \\
\text { wound space until level with } \\
\text { skin surface. } \\
\end{array}$ & Twice per week for 6 weeks. & $\begin{array}{c}\text { APC reduced wound area to } 36.8 \\
\pm 16.4 \% \text { of week } 0 \text { levels at } 20 \\
\text { weeks, while control had no } \\
\text { significant difference. }\end{array}$ \\
\hline
\end{tabular}




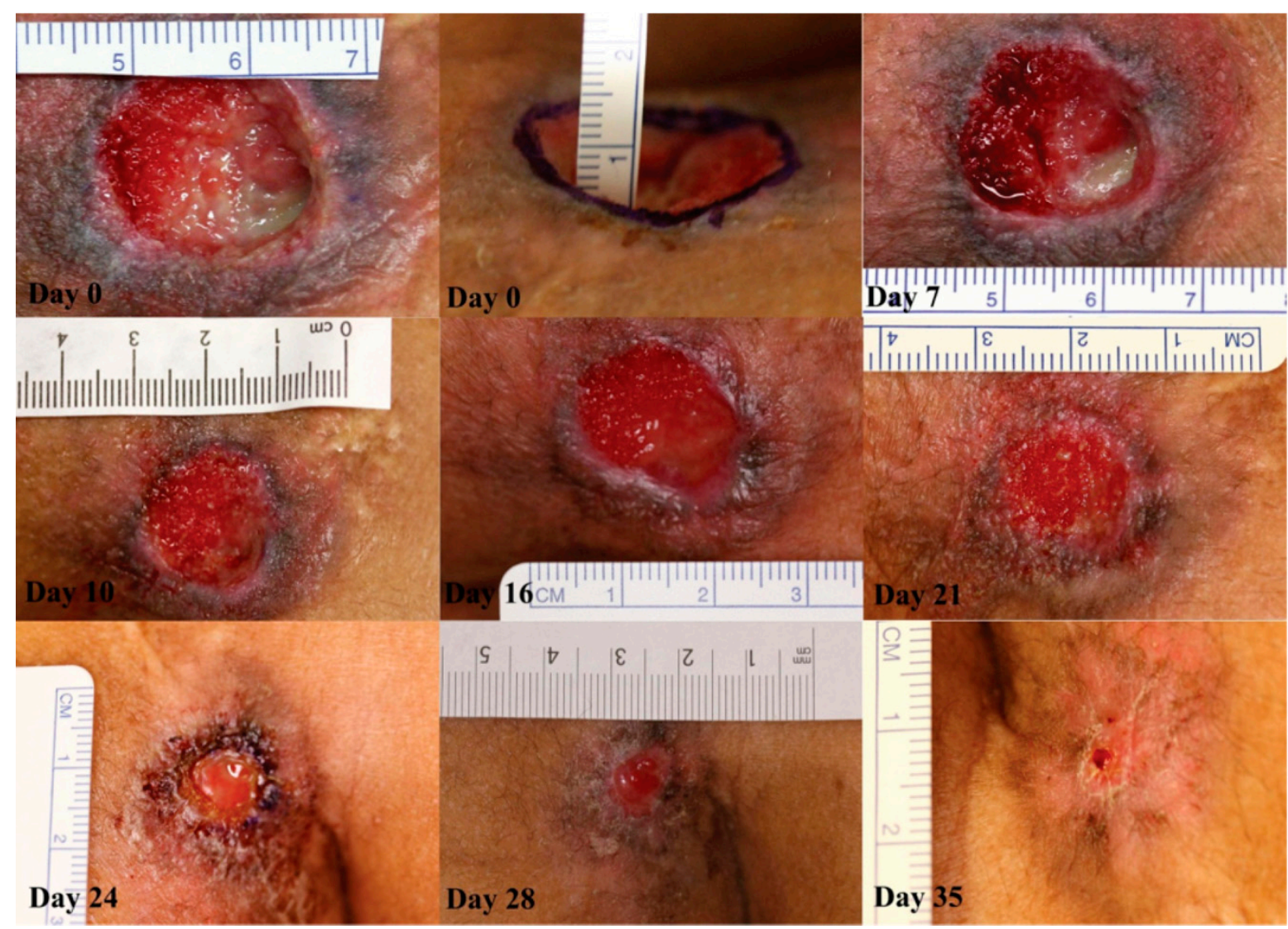

Figure 4. Case 1: sacral pressure ulcer progression through healing after activated protein C (APC) administration. On day 0 , the wound had a central depth of $10 \mathrm{~mm}$. At day 7, the wound was 20 $\mathrm{mm}$ in diameter. Rapid growth of granulation tissue is apparent from day 7 to day 16 . At day 16 , the diameter was $18 \mathrm{~mm}$. On day 21, the diameter was $14 \mathrm{~mm}$, and by day 24 the wound was $6 \mathrm{~mm}$ in diameter. Therapy was stopped at this point. At day 28, the diameter was $5 \mathrm{~mm}$. Final follow-up at day 35 showed that the wound had healed completely. No images of the follow-up. (C) 2014 The Authors. International Wound Journal @ 2014 Medicalhelplines.com Inc and John Wiley \& Sons Ltd. Reproduced with permission. License number 4525880595450.

\section{Exogenous APC}

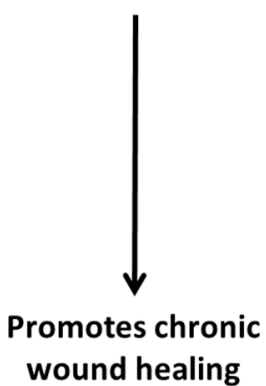

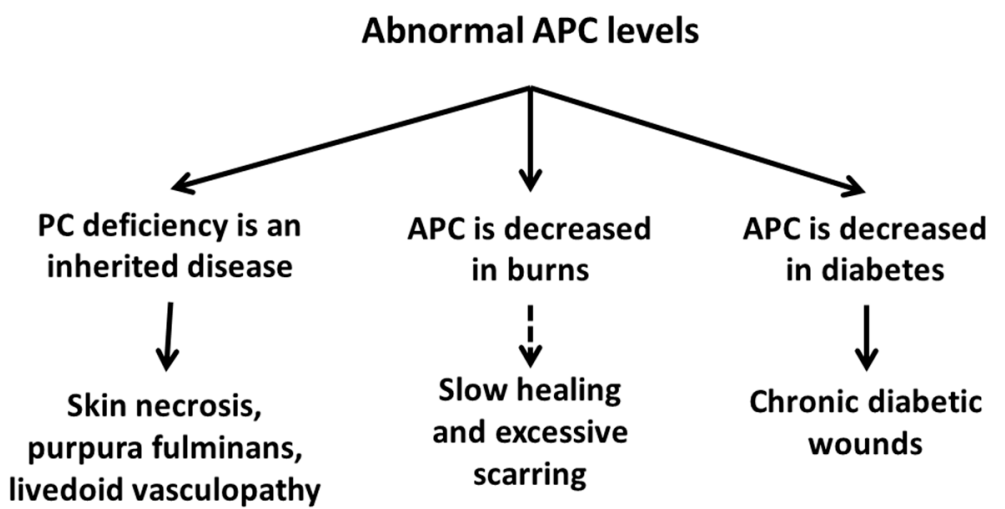

Figure 5. In humans, low APC levels are associated with chronic diabetic wounds, severe burn injuries, and skin necrosis secondary to purpura fulminans. Exogenous APC has been shown to promote the healing of chronic wounds of varying aetiologies. 


\section{Active Protein C in Other Diseases}

APC may also have therapeutic benefits in a number of other diseases, including sepsis [13], central nervous system injury [78], ischaemic stroke [14], Alzheimer's disease [79], acute kidney injury [80], lung disorders [81], acute pancreatitis [82], type I diabetes [83], rheumatoid arthritis [33,84], and cancer [85] (Table 3). Besides its obvious use in homozygous PC deficiency, APC has only been approved for severe sepsis. PC levels are known to be a strong prognostic factor in septic patients [86]. Due to this, and its pleiotropic anticoagulative and cytoprotective properties, APC has been long been suggested to treat sepsis. Activated drotrecogin alpha, or recombinant human APC (rhAPC), was the first U.S. Food and Drug Administration (FDA)-approved drug for the treatment of severe sepsis in 2001. Evidence from two large clinical trials suggested rhAPC reduces mortality, but may have increased the risk of bleeding [64,87]. However, since then, APC has been the subject of much controversy with regards to its efficacy and safety in certain patient populations, such as those with single organ dysfunction who have recently undergone surgery (within 30 days) [88,89]. Published in 2012, the results of another large trial showed that rhAPC did not significantly reduce mortality [90]. This resulted in Eli Lilly, a global pharmaceutical company that produced rhAPC, to voluntarily withdraw their drug from public use worldwide in 2011. A series of Cochrane reviews in 2011 and 2012 concluded that despite the scientific rationale, there is insufficient data for APC's use in septic neonates, children or adults, and advised against its further promotion [91-93]. However, further developments in mutant APC, without its anticoagulant properties, have reinvigorated research into its potential benefits.

Table 3. Examples of APC's therapeutic benefits in other diseases.

\begin{tabular}{cc}
\hline Study & Disease \\
\hline Yamauchi et al. [78] & Spinal cord ischaemia \\
Cornet et al. [81] & Acute lung injury and acute respiratory distress syndrome \\
Gupta et al. [80] & Acute kidney injury \\
Shankar-Hari and Wyncoll [82] & Acute pancreatitis \\
Spek and Arruda [85] & Cancer \\
Xue et al. [83] & Type I diabetes \\
Li et al. [79] & Alzheimer's disease \\
Zhang [13] & Sepsis \\
Amar et al. [14] & Ischaemic stroke \\
Xue et al. [84] & Rheumatoid arthritis \\
\hline
\end{tabular}

It should be emphasised that no side effects, including toxicity or bleeding, were noted in the animal and human wound studies. This is likely resultant from local applications of APC as opposed to systematic, as in the sepsis studies.

\section{Engineered Protein C/Active Protein C}

APC's potent anticoagulation activity involves stereospecific interactions with factors Va and VIIIa at both its enzymatic active site and secondary binding sides, called exosites [94]. These exosites differ from the ones needed for binding to EPCR and PAR-1, and thus can be mutated to diminish the anticoagulation effects of APC while preserving its cytoprotective properties [95,96]. Mosnier et al. [95] generated two variants-229/230-APC (RR229/230AA) and 3K3A-APC (KKK191-193AAA-in which a cluster of positive residues were replaced by two and three alanine residues, respectively, restructuring a crucial positive region for binding factor Va. These two mutations severely reduced APC's anticoagulation activity but retained normal anti-apoptotic actions. The same group later showed that combining the two mutations formed a new variant-5A-APC-with even less anticoagulation activity $(<0.1 \%$ FVa inactivation compared to wild type APC), but normal cytoprotective activity in cells [97]. Bae et al. [98] confirmed the distinction between the anticoagulant and cytoprotective exosites of APC by engineering a disulphide bond between two $\beta$-sheets, 
which stabilised the functionally critical $\mathrm{Ca}^{2+}$-binding 70-80 loop, yielding similar results to the previous two studies. Various other mutations have been characterised to elucidate the underlying mechanisms to APC's pleiotropic functions; the numerous mutational studies of APC are summarised by Sarangi et al. [99]. These have included changes in anticoagulation, cytoprotection, cofactor dependency, and half-life, among others. Specifically, the mutations that minimise anticoagulation produced variants that have equivalent or sometimes even greater beneficial effects than wild-type recombinant APC, as demonstrated in animal models of stroke [100-105], traumatic brain injury [106], amyotropic lateral sclerosis [107], endotoxaemia and sepsis mortality [108-110], myocardial and liver ischaemic/reperfusion injury [111-113], and Pseudomonas aeruginosa pneumonia [114]. A notable example (APC-L38D/N329Q) was generated with five-fold enhanced endothelial barrier protective function, as well as 30-fold improved anti-apoptotic function [115]. Important examples pertaining to cytoprotection are summarised in Table 4. A synthetic 20-mer peptide (TR47) consisting of the APC-cleaved N-terminus of PAR-1, has further been described with pharmacological actions resembling those of APC [27].

Table 4. Notable examples of mutational studies for cytoprotection.

\begin{tabular}{|c|c|c|c|}
\hline Study & Name & Mutation & Effects \\
\hline Mosnier et al. [95] & 3K3A-APC & $\begin{array}{l}\text { Alanine mutations of } \\
\text { FVa-binding residues } \\
\text { (KKK191_193AAA) }\end{array}$ & \multirow[t]{2}{*}{$\begin{array}{l}\text { Reduced anticoagulant activity, with } \\
\text { normal anti-apoptotic functions }\end{array}$} \\
\hline Bae et al. [98] & No name given & $\begin{array}{l}\text { Disulfide bond between two } \\
\beta \text {-sheets }\left(\mathrm{Cys}^{67}-\mathrm{Cys}^{82}\right)\end{array}$ & \\
\hline Ni Ainle et al. [115] & APC-L38D/N329Q & $\begin{array}{l}\text { Elimination of an } N \text {-linked } \\
\text { glycan attachment site } \\
\text { (L38D/N329Q) }\end{array}$ & $\begin{array}{l}\text { Reduced anticoagulant activity, and } \\
\text { improved endothelial barrier protective } \\
\text { and anti-apoptotic functions }\end{array}$ \\
\hline
\end{tabular}

Mosnier et al. [110] generated another APC mutant (E149A-APC) with greatly reduced cytoprotective effects but superior anticoagulant activity, which has been useful for proof-of-concept studies and for antithrombotic indications. Experiments comparing E149A-APC to wild-type APC and 5A-APC further emphasise that APC's anticoagulant property is unnecessary to confer its cytoprotective activities $[105,110]$.

Notably, 3K3A-APC has successfully completed both Phase I and II trials for ischaemic stroke [116,117], but is yet to be assessed in wound healing. Recent work from our group has shown 3K3A-APC accelerates excisional wound healing in mice and pigs, including promoting collagen maturation in pigs. The FDA is currently being approached for approval to conduct a Phase II trial on diabetic foot ulcers.

Although these variants are yet to be assessed in the field of clinical wound healing, the engineered APCs are expected to exert similar anti-inflammatory and cytoprotective actions in the skin as they have demonstrated in other tissue and disease models. Furthermore, the potential side-effect of APC to increase bleeding in wounds has not been seen in studies so far, and appears to be circumvented by both engineered variants and topical and subcutaneous applications, instead of systemic.

\section{Conclusions}

APC's multimodal actions make it an extremely useful and versatile agent in a wide range of disease areas. Since the start of the millennium, its role in wound healing has embarked on a journey of discovery from cell culture to animal studies, and to small clinical trials. APC's remarkable wound healing properties have been extensively demonstrated, and its mechanisms thoroughly elucidated. 
Its future now may well lie in one of its engineered variants, with greater cytoprotection and fewer anticoagulation properties. Of these, 3K3A-APC is poised to take the next step in human clinical trials.

Author Contributions: R.Z., C.J. and M.X. conceived the idea; R.Z. wrote the manuscript; C.J., M.X., E.C., H.L. and L.B.-M. contributed to the writing of manuscript.

Funding: This work received no external funding.

Acknowledgments: This work was supported by the National Health and Medical Research Council, University of Sydney Medical Foundation, Ramsay Healthcare, and the Northern Sydney Local Health Service.

Conflicts of Interest: Chris Jackson and Meilang Xue are the inventors of patents and have commercial interests in APC-related drugs.

\section{Abbreviations}

\begin{tabular}{|c|c|}
\hline APC & activated protein $C$ \\
\hline ApoER2 & apolipoprotein E receptor 2 \\
\hline EGF & epidermal growth factor \\
\hline EGFR & EGF receptor \\
\hline eNOS & endothelial nitric oxide synthase \\
\hline EPCR & endothelial protein $C$ receptor \\
\hline HUVEC & human umbilical vein endothelial cell \\
\hline MCP & monocyte chemoattractant protein \\
\hline MMP & matrix metalloprotein \\
\hline NF & nuclear factor \\
\hline NLRP3 & (NOD)-like receptor protein 3 \\
\hline PAR & protease-activated receptor \\
\hline PC & protein $C$ \\
\hline rhAPC & recombinant human APC \\
\hline S1P & sphingosine-1-phosphate \\
\hline S1P1 & sphingosine-1-phosphate receptor 1 \\
\hline TNF & tumour necrosis factor \\
\hline TPN & topical negative pressure \\
\hline VEGF & vascular endothelial growth factor \\
\hline
\end{tabular}

\section{References}

1. Mammen, E.F.; Thomas, W.R.; Seegers, W.H. Activation of purified prothrombin to autoprothrombin I or autoprothrombin II (platelet cofactor II or autoprothrombin II-A). Thromb. Diath Haemorrh. 1960, 5, 218-249. [CrossRef] [PubMed]

2. Stenflo, J. A new vitamin K-dependent protein. Purification from bovine plasma and preliminary characterization. J. Biol. Chem. 1976, 251, 355-363. [PubMed]

3. Griffin, J.H.; Fernandez, J.A.; Gale, A.J.; Mosnier, L.O. Activated protein C. J. Thromb. Haemost. 2007, 5, 73-80. [CrossRef] [PubMed]

4. D'Ursi, P.; Marino, F.; Caprera, A.; Milanesi, L.; Faioni, E.M.; Rovida, E. ProCMD: A database and 3D web resource for protein C mutants. BMC Bioinform. 2007, 8, S11. [CrossRef]

5. Mosnier, L.O.; Griffin, J.H. Protein C anticoagulant activity in relation to anti-inflammatory and anti-apoptotic activities. Front. Biosci. 2006, 11, 2381-2399. [CrossRef]

6. Gruber, A.; Griffin, J.H. Direct detection of activated protein C in blood from human subjects. Blood 1992, 79, 2340-2348.

7. Stearns-Kurosawa, D.J.; Kurosawa, S.; Mollica, J.S.; Ferrell, G.L.; Esmon, C.T. The endothelial cell protein $\mathrm{C}$ receptor augments protein $\mathrm{C}$ activation by the thrombin-thrombomodulin complex. Proc. Natl. Acad. Sci. USA 1996, 93, 10212-10216. [CrossRef]

8. Fukudome, K.; Esmon, C.T. Identification, cloning, and regulation of a novel endothelial cell protein C/activated protein C receptor. J. Biol. Chem. 1994, 269, 26486-26491. 
9. Xue, M.; Campbell, D.; Jackson, C.J. Protein C is an autocrine growth factor for human skin keratinocytes. J. Biol. Chem. 2007, 282, 13610-13616. [CrossRef]

10. Xue, M.; Campbell, D.; Sambrook, P.N.; Fukudome, K.; Jackson, C.J. Endothelial protein C receptor and protease-activated receptor-1 mediate induction of a wound-healing phenotype in human keratinocytes by activated protein C. J. Invest. Dermatol. 2005, 125, 1279-1285. [CrossRef]

11. Jackson, D.E.; Mitchell, C.A.; Bird, P.; Salem, H.H.; Hayman, J.A. Immunohistochemical localization of thrombomodulin in normal human skin and skin tumours. J. Pathol. 1995, 175, 421-432. [CrossRef] [PubMed]

12. Xue, M.; Chow, S.O.; Dervish, S.; Chan, Y.K.; Julovi, S.M.; Jackson, C.J. Activated protein C enhances human keratinocyte barrier integrity via sequential activation of epidermal growth factor receptor and Tie2. J. Biol. Chem. 2011, 286, 6742-6750. [CrossRef] [PubMed]

13. Zhang, Z. The efficacy of activated protein $C$ for the treatment of sepsis: Incorporating observational evidence with a Bayesian approach. BMJ Open 2015, 5, e006524. [CrossRef] [PubMed]

14. Amar, A.P.; Sagare, A.P.; Zhao, Z.; Wang, Y.; Nelson, A.R.; Griffin, J.H.; Zlokovic, B.V. Can adjunctive therapies augment the efficacy of endovascular thrombolysis? A potential role for activated protein C. Neuropharmacology 2018, 134, 293-301. [CrossRef] [PubMed]

15. Zhao, R.; Liang, H.; Clarke, E.; Jackson, C.; Xue, M. Inflammation in Chronic Wounds. Int. J. Mol. Sci. 2016, 17, 2085. [CrossRef] [PubMed]

16. Dahlback, B. Protein S and C4b-binding protein: Components involved in the regulation of the protein C anticoagulant system. Thromb. Haemost. 1991, 66, 49-61. [CrossRef] [PubMed]

17. Rezaie, A.R. Regulation of the protein $\mathrm{C}$ anticoagulant and antiinflammatory pathways. Curr. Med. Chem. 2010, 17, 2059-2069. [CrossRef]

18. Walker, F.J.; Fay, P.J. Regulation of blood coagulation by the protein C system. FASEB J. 1992, 6, $2561-2567$. [CrossRef]

19. Esmon, C.T. Molecular events that control the protein C anticoagulant pathway. Thromb. Haemost. 1993, 70, 29-35. [CrossRef]

20. Chalmers, E.; Cooper, P.; Forman, K.; Grimley, C.; Khair, K.; Minford, A.; Morgan, M.; Mumford, A.D. Purpura fulminans: Recognition, diagnosis and management. Arch. Dis. Child. 2011, 96, 1066-1071. [CrossRef]

21. Mosnier, L.O.; Zlokovic, B.V.; Griffin, J.H. The cytoprotective protein C pathway. Blood 2007, 109, 3161-3172. [CrossRef] [PubMed]

22. Riewald, M.; Petrovan, R.J.; Donner, A.; Mueller, B.M.; Ruf, W. Activation of endothelial cell protease activated receptor 1 by the protein C pathway. Science 2002, 296, 1880-1882. [CrossRef] [PubMed]

23. Esmon, C.T. Structure and functions of the endothelial cell protein C receptor. Crit. Care Med. 2004, 32, S298-S301. [CrossRef] [PubMed]

24. Ludeman, M.J.; Kataoka, H.; Srinivasan, Y.; Esmon, N.L.; Esmon, C.T.; Coughlin, S.R. PAR1 cleavage and signaling in response to activated protein C and thrombin. J. Biol. Chem. 2005, 280, 13122-13128. [CrossRef] [PubMed]

25. Russo, A.; Soh, U.J.; Paing, M.M.; Arora, P.; Trejo, J. Caveolae are required for protease-selective signaling by protease-activated receptor-1. Proc. Natl. Acad. Sci. USA 2009, 106, 6393-6397. [CrossRef] [PubMed]

26. Bae, J.S.; Yang, L.; Rezaie, A.R. Receptors of the protein C activation and activated protein $C$ signaling pathways are colocalized in lipid rafts of endothelial cells. Proc. Natl. Acad. Sci. USA 2007, 104, 2867-2872. [CrossRef]

27. Mosnier, L.O.; Sinha, R.K.; Burnier, L.; Bouwens, E.A.; Griffin, J.H. Biased agonism of protease-activated receptor 1 by activated protein C caused by noncanonical cleavage at Arg46. Blood 2012, 120, 5237-5246. [CrossRef]

28. Bouwens, E.A.; Stavenuiter, F.; Mosnier, L.O. Mechanisms of anticoagulant and cytoprotective actions of the protein C pathway. J. Thromb. Haemost. 2013, 11, 242-253. [CrossRef]

29. Franscini, N.; Bachli, E.B.; Blau, N.; Leikauf, M.S.; Schaffner, A.; Schoedon, G. Gene expression profiling of inflamed human endothelial cells and influence of activated protein C. Circulation 2004, 110, 2903-2909. [CrossRef]

30. Jackson, C.; Xue, M. Anti-inflammatory actions of the anticoagulant, activated protein C. In Inflammatory Diseases - A Modern Perspective; Nagal, A., Ed.; InTech: Rijeka, Croatia, 2011; pp. 42-74. 
31. Brueckmann, M.; Hoffmann, U.; De Rossi, L.; Weiler, H.M.; Liebe, V.; Lang, S.; Kaden, J.J.; Borggrefe, M.; Haase, K.K.; Huhle, G. Activated protein C inhibits the release of macrophage inflammatory protein-1-alpha from THP-1 cells and from human monocytes. Cytokine 2004, 26, 106-113. [CrossRef]

32. Yuksel, M.; Okajima, K.; Uchiba, M.; Horiuchi, S.; Okabe, H. Activated protein C inhibits lipopolysaccharide-induced tumor necrosis factor-alpha production by inhibiting activation of both nuclear factor-kappa B and activator protein-1 in human monocytes. Thromb. Haemost. 2002, 88, 267-273. [CrossRef] [PubMed]

33. Xue, M.; March, L.; Sambrook, P.N.; Jackson, C.J. Differential regulation of matrix metalloproteinase 2 and matrix metalloproteinase 9 by activated protein C: Relevance to inflammation in rheumatoid arthritis. Arthritis. Rheum. 2007, 56, 2864-2874. [CrossRef]

34. Nazir, S.; Gadi, I.; Al-Dabet, M.M.; Elwakiel, A.; Kohli, S.; Ghosh, S.; Manoharan, J.; Ranjan, S.; Bock, F.; Braun-Dullaeus, R.C.; et al. Cytoprotective activated protein C averts Nlrp3 inflammasome-induced ischemia-reperfusion injury via mTORC1 inhibition. Blood 2017, 130, 2664-2677. [CrossRef]

35. Joyce, D.E.; Gelbert, L.; Ciaccia, A.; DeHoff, B.; Grinnell, B.W. Gene expression profile of antithrombotic protein c defines new mechanisms modulating inflammation and apoptosis. J. Biol. Chem. 2001, 276, 11199-11203. [CrossRef] [PubMed]

36. Bezuhly, M.; Morris, S.F.; Juskevicius, R.; Currie, R.W.; West, K.A.; Liwski, R.S. Activated protein C improves ischemic flap survival and modulates proangiogenic and antiinflammatory gene expression. Plast Reconstr. Surg. 2009, 123, 502-515. [CrossRef] [PubMed]

37. Cheng, T.; Liu, D.; Griffin, J.H.; Fernandez, J.A.; Castellino, F.; Rosen, E.D.; Fukudome, K.; Zlokovic, B.V. Activated protein $\mathrm{C}$ blocks p53-mediated apoptosis in ischemic human brain endothelium and is neuroprotective. Nat. Med. 2003, 9, 338-342. [CrossRef]

38. Xue, M.; Thompson, P.; Kelso, I.; Jackson, C. Activated protein C stimulates proliferation, migration and wound closure, inhibits apoptosis and upregulates MMP-2 activity in cultured human keratinocytes. Exp. Cell Res. 2004, 299, 119-127. [CrossRef] [PubMed]

39. Uchiba, M.; Okajima, K.; Oike, Y.; Ito, Y.; Fukudome, K.; Isobe, H.; Suda, T. Activated protein C induces endothelial cell proliferation by mitogen-activated protein kinase activation in vitro and angiogenesis in vivo. Circ. Res. 2004, 95, 34-41. [CrossRef] [PubMed]

40. Feistritzer, C.; Riewald, M. Endothelial barrier protection by activated protein C through PAR1-dependent sphingosine 1-phosphate receptor-1 crossactivation. Blood 2005, 105, 3178-3184. [CrossRef]

41. Burridge, K.; Wennerberg, K. Rho and Rac take center stage. Cell 2004, 116, 167-179. [CrossRef]

42. Minhas, N.; Xue, M.; Fukudome, K.; Jackson, C.J. Activated protein C utilizes the angiopoietin/Tie2 axis to promote endothelial barrier function. FASEB J. 2010, 24, 873-881. [CrossRef] [PubMed]

43. Xue, M.; Minhas, N.; Chow, S.O.; Dervish, S.; Sambrook, P.N.; March, L.; Jackson, C.J. Endogenous protein $\mathrm{C}$ is essential for the functional integrity of human endothelial cells. Cell Mol. Life Sci. 2010, 67, 1537-1546. [CrossRef] [PubMed]

44. Vetrano, S.; Ploplis, V.A.; Sala, E.; Sandoval-Cooper, M.; Donahue, D.L.; Correale, C.; Arena, V.; Spinelli, A.; Repici, A.; Malesci, A.; et al. Unexpected role of anticoagulant protein C in controlling epithelial barrier integrity and intestinal inflammation. Proc. Natl. Acad. Sci. USA 2011, 108, 19830-19835. [CrossRef] [PubMed]

45. Puig, F.; Fuster, G.; Adda, M.; Blanch, L.; Farre, R.; Navajas, D.; Artigas, A. Barrier-protective effects of activated protein C in human alveolar epithelial cells. PLoS ONE 2013, 8, e56965. [CrossRef]

46. Griffin, J.H.; Zlokovic, B.V.; Mosnier, L.O. Protein C anticoagulant and cytoprotective pathways. Int. J. Hematol. 2012, 95, 333-345. [CrossRef]

47. Minhas, N.; Xue, M.; Jackson, C.J. Activated protein C binds directly to Tie2: Possible beneficial effects on endothelial barrier function. Cell Mol. Life Sci. 2017, 74, 1895-1906. [CrossRef]

48. Cao, C.; Gao, Y.; Li, Y.; Antalis, T.M.; Castellino, F.J.; Zhang, L. The efficacy of activated protein C in murine endotoxemia is dependent on integrin CD11b. J. Clin. Invest. 2010, 120, 1971-1980. [CrossRef]

49. Madhusudhan, T.; Wang, H.; Straub, B.K.; Grone, E.; Zhou, Q.; Shahzad, K.; Muller-Krebs, S.; Schwenger, V.; Gerlitz, B.; Grinnell, B.W.; et al. Cytoprotective signaling by activated protein $\mathrm{C}$ requires protease-activated receptor-3 in podocytes. Blood 2012, 119, 874-883. [CrossRef] 
50. Bock, F.; Shahzad, K.; Wang, H.; Stoyanov, S.; Wolter, J.; Dong, W.; Pelicci, P.G.; Kashif, M.; Ranjan, S.; Schmidt, S.; et al. Activated protein $\mathrm{C}$ ameliorates diabetic nephropathy by epigenetically inhibiting the redox enzyme p66Shc. Proc. Natl. Acad. Sci. USA 2013, 110, 648-653. [CrossRef]

51. Feistritzer, C.; Schuepbach, R.A.; Mosnier, L.O.; Bush, L.A.; Di Cera, E.; Griffin, J.H.; Riewald, M. Protective signaling by activated protein $\mathrm{C}$ is mechanistically linked to protein $\mathrm{C}$ activation on endothelial cells. J. Biol. Chem. 2006, 281, 20077-20084. [CrossRef]

52. Gramling, M.W.; Beaulieu, L.M.; Church, F.C. Activated protein C enhances cell motility of endothelial cells and MDA-MB-231 breast cancer cells by intracellular signal transduction. Exp. Cell Res. 2010, 316, 314-328. [CrossRef] [PubMed]

53. Yoshida, K.; Akita, N.; Okamoto, T.; Asanuma, K.; Uchida, A.; Sudo, A.; Shimaoka, M.; Suzuki, K.; Hayashi, T. Activated protein $\mathrm{C}$ suppresses osteoclast differentiation via endothelial protein $\mathrm{C}$ receptor, protease-activated receptor-1, sphingosine 1-phosphate receptor, and apolipoprotein E receptor 2. Thromb. Res. 2018, 163, 30-40. [CrossRef]

54. Julovi, S.M.; Xue, M.; Dervish, S.; Sambrook, P.N.; March, L.; Jackson, C.J. Protease activated receptor-2 mediates activated protein C-induced cutaneous wound healing via inhibition of p38. Am. J. Pathol. 2011, 179, 2233-2242. [CrossRef]

55. Ranjan, S.; Goihl, A.; Kohli, S.; Gadi, I.; Pierau, M.; Shahzad, K.; Gupta, D.; Bock, F.; Wang, H.; Shaikh, H.; et al. Activated protein C protects from GvHD via PAR2/PAR3 signalling in regulatory T-cells. Nat. Commun. 2017, 8, 311. [CrossRef] [PubMed]

56. McKelvey, K.; Jackson, C.J.; Xue, M. Activated protein C: A regulator of human skin epidermal keratinocyte function. World J. Biol. Chem. 2014, 5, 169-179. [PubMed]

57. Jackson, C.; Xue, M. Activated Protein C (APC) as a Novel Agent to Promote Wound Healing Primary Intention. Aust. J. Wound Manag. 2006, 14, 31-34.

58. Jackson, C.J.; Xue, M.; Thompson, P.; Davey, R.A.; Whitmont, K.; Smith, S.; Buisson-Legendre, N.; Sztynda, T.; Furphy, L.J.; Cooper, A.; et al. Activated protein C prevents inflammation yet stimulates angiogenesis to promote cutaneous wound healing. Wound Repair Regen. 2005, 13, 284-294. [CrossRef] [PubMed]

59. Brueckmann, M.; Marx, A.; Weiler, H.M.; Liebe, V.; Lang, S.; Kaden, J.J.; Zieger, W.; Borggrefe, M.; Huhle, G.; Haase, K.K. Stabilization of monocyte chemoattractant protein-1-mRNA by activated protein C. Thromb. Haemost. 2003, 89, 149-160.

60. Bretschneider, E.; Uzonyi, B.; Weber, A.A.; Fischer, J.W.; Pape, R.; Lotzer, K.; Schror, K. Human vascular smooth muscle cells express functionally active endothelial cell protein C receptor. Circ. Res. 2007, 100, 255-262. [CrossRef] [PubMed]

61. Bischofberger, A.S.; Tsang, A.S.; Horadagoda, N.; Dart, C.M.; Perkins, N.R.; Jeffcott, L.B.; Jackson, C.J.; Dart, A.J. Effect of activated protein $C$ in second intention healing of equine distal limb wounds: A preliminary study. Aust. Vet. J. 2015, 93, 361-366. [CrossRef]

62. Nisanci, M.; Eski, M.; Sahin, I.; Ilgan, S.; Isik, S. Saving the zone of stasis in burns with activated protein C: An experimental study in rats. Burns 2010, 36, 397-402. [CrossRef] [PubMed]

63. Meyerholz, D.K.; Piester, T.L.; McNamara, A.R.; Sokolich, J.C.; Jaskille, A.D.; Orion, K.C.; Zamba, K.D.; Light, T.D. Pharmacologic modification to resuscitation fluid after thermal injury-is drotrecogin alfa the answer to arrest burn depth progression? J. Trauma 2009, 67, 996-1003. [CrossRef] [PubMed]

64. Bernard, G.R.; Vincent, J.L.; Laterre, P.F.; LaRosa, S.P.; Dhainaut, J.F.; Lopez-Rodriguez, A.; Steingrub, J.S.; Garber, G.E.; Helterbrand, J.D.; Ely, E.W.; et al. Efficacy and safety of recombinant human activated protein C for severe sepsis. N. Engl. J. Med. 2001, 344, 699-709. [CrossRef] [PubMed]

65. Davenport, R. Pathogenesis of acute traumatic coagulopathy. Transfusion 2013, 53, 23S-27S. [CrossRef]

66. Eming, S.A.; Martin, P.; Tomic-Canic, M. Wound repair and regeneration: Mechanisms, signaling, and translation. Sci. Transl. Med. 2014, 6, 265sr6. [CrossRef]

67. Rudolph, R. Location of the force of wound contraction. Surg. Gynecol. Obstet. 1979, 148, 547-551.

68. McGrath, M.H.; Simon, R.H. Wound geometry and the kinetics of wound contraction. Plast. Reconstr. Surg. 1983, 72, 66-73. [CrossRef]

69. Volk, S.W.; Bohling, M.W. Comparative wound healing-are the small animal veterinarian's clinical patients an improved translational model for human wound healing research? Wound Repair Regen. 2013, 21, 372-381. [CrossRef] 
70. Sullivan, T.P.; Vincent, J.L.; Laterre, P.F.; LaRosa, S.P.; Dhainaut, J.F.; Lopez-Rodriguez, A.; Steingrub, J.S.; Garber, G.E.; Helterbrand, J.D.; Ely, E.W.; et al. The pig as a model for human wound healing. Wound Repair Regen. 2001, 9, 66-76. [CrossRef]

71. Mustoe, T. Understanding chronic wounds: A unifying hypothesis on their pathogenesis and implications for therapy. Am. J. Surg. 2004, 187, S65-S70. [CrossRef]

72. Whitmont, K.; Reid, I.; Tritton, S.; March, L.; Xue, M.; Lee, M.; Fulcher, G.; Sambrook, P.; Slobedman, E.; Cooper, A.; Jackson, C. Treatment of chronic leg ulcers with topical activated protein C. Arch. Dermatol. 2008, 144, 1479-1483. [CrossRef]

73. Whitmont, K.; Fulcher, G.; Reid, I.; Xue, M.; McKelvey, K.; Xie, Y.; Aboud, M.; Ward, C.; Smith, M.M.; Cooper, A.; et al. Low circulating protein $\mathrm{C}$ levels are associated with lower leg ulcers in patients with diabetes. Biomed. Res. Int. 2013, 2013, 719570. [CrossRef]

74. Wijewardena, A.; Vandervord, E.; Lajevardi, S.S.; Vandervord, J.; Jackson, C.J. Combination of activated protein $C$ and topical negative pressure rapidly regenerates granulation tissue over exposed bone to heal recalcitrant orthopedic wounds. Int. J. Low Extrem. Wounds 2011, 10, 146-151. [CrossRef]

75. Whitmont, K.; Vandervord, E.; Lajevardi, S.S.; Vandervord, J.; Jackson, C.J. Treatment of chronic diabetic lower leg ulcers with activated protein C: A randomised placebo-controlled, double-blind pilot clinical trial. Int. Wound J. 2015, 12, 422-427. [CrossRef]

76. Kapila, S.; Reid, I.; Dixit, S.; Fulcher, G.; March, L.; Jackson, C.; Cooper, A. Use of dermal injection of activated protein $\mathrm{C}$ for treatment of large chronic wounds secondary to pyoderma gangrenosum. Clin. Exp. Dermatol. 2014, 39, 785-790. [CrossRef]

77. Wijewardena, A.; Lajevardi, S.S.; Vandervord, E.; Vandervord, J.; Lang, T.C.; Fulcher, G.; Jackson, C.J. Activated protein C to heal pressure ulcers. Int. Wound J. 2016, 13, 986-991. [CrossRef]

78. Yamauchi, T.; Sakurai, M.; Abe, K.; Takano, H.; Sawa, Y. Neuroprotective effects of activated protein $C$ through induction of insulin-like growth factor-1 (IGF-1), IGF-1 receptor, and its downstream signal phosphorylated serine-threonine kinase after spinal cord ischemia in rabbits. Stroke 2006, 37, 1081-1086. [CrossRef]

79. Li, B.; Yu, D.; Xu, Z. Activated protein C inhibits amyloid beta production via promoting expression of ADAM-10. Brain Res. 2014, 1545, 35-44. [CrossRef]

80. Gupta, A.; Gerlitz, B.; Richardson, M.A.; Bull, C.; Berg, D.T.; Syed, S.; Galbreath, E.J.; Swanson, B.A.; Jones, B.E.; Grinnell, B.W. Distinct functions of activated protein C differentially attenuate acute kidney injury. J. Am. Soc. Nephrol. 2009, 20, 267-277. [CrossRef]

81. Cornet, A.D.; van Nieuw Amerongen, G.P.; Beishuizen, A.; Schultz, M.J.; Girbes, A.R.; Groeneveld, A.J. Activated protein $\mathrm{C}$ in the treatment of acute lung injury and acute respiratory distress syndrome. Expert Opin. Drug. Discov. 2009, 4, 219-227. [CrossRef]

82. Shankar-Hari, M.; Wyncoll, D. Activated protein C in severe acute pancreatitis without sepsis? Not just yet. Crit. Care 2010, 14, 188. [CrossRef]

83. Xue, M.; Dervish, S.; Harrison, L.C.; Fulcher, G.; Jackson, C.J. Activated protein C inhibits pancreatic islet inflammation, stimulates T regulatory cells, and prevents diabetes in non-obese diabetic (NOD) mice. J. Biol. Chem. 2012, 287, 16356-16364. [CrossRef]

84. Xue, M.; Dervish, S.; McKelvey, K.J.; March, L.; Wang, F.; Little, C.B.; Jackson, C.J. Activated protein C targets immune cells and rheumatoid synovial fibroblasts to prevent inflammatory arthritis in mice. Rheumatology 2019. [Epub ahead of print]. [CrossRef]

85. Spek, C.A.; Arruda, V.R. The protein C pathway in cancer metastasis. Thromb. Res. 2012, 129, S80-S84. [CrossRef]

86. Fisher, C.J., Jr.; Yan, S.B. Protein C levels as a prognostic indicator of outcome in sepsis and related diseases. Crit. Care Med. 2000, 28, S49-S56. [CrossRef]

87. Bernard, G.R.; Margolis, B.D.; Shanies, H.M.; Ely, E.W.; Wheeler, A.P.; Levy, H.; Wong, K.; Wright, T.J. Extended evaluation of recombinant human activated protein $C$ United States Trial (ENHANCE US): A single-arm, phase 3B, multicenter study of drotrecogin alfa (activated) in severe sepsis. Chest 2004, 125, 2206-2216. [CrossRef]

88. Sandrock, C.E.; Albertson, T.E. Controversies in the treatment of sepsis. Semin Respir. Crit. Care Med. 2010, 31, 66-78. [CrossRef]

89. Alaniz, C. An update on activated protein C (xigris) in the management of sepsis. P T 2010, 35, 504-529. 
90. Ranieri, V.M.; Thompson, B.T.; Barie, P.S.; Dhainaut, J.F.; Douglas, I.S.; Finfer, S.; Gardlund, B.; Marshall, J.C.; Rhodes, A.; Artigas, A.; et al. Drotrecogin alfa (activated) in adults with septic shock. N. Engl. J. Med. 2012, 366, 2055-2064. [CrossRef]

91. Marti-Carvajal, A.J.; Sola, I.; Gluud, C.; Lathyris, D.; Cardona, A.F. Human recombinant activated protein C for severe sepsis. Cochrane Database Syst. Rev. 2012, 3, CD004388.

92. Kylat, R.I.; Ohlsson, A. Recombinant human activated protein $\mathrm{C}$ for severe sepsis in neonates. Cochrane Database Syst. Rev. 2012, 4, CD005385. [CrossRef]

93. Marti-Carvajal, A.J.; Sola, I.; Gluud, C.; Lathyris, D.; Cardona, A.F. Human recombinant protein C for severe sepsis and septic shock in adult and paediatric patients. Cochrane Database Syst. Rev. 2012, 12, CD004388. [CrossRef]

94. Zlokovic, B.V.; Griffin, J.H. Cytoprotective protein C pathways and implications for stroke and neurological disorders. Trends Neurosci. 2011, 34, 198-209. [CrossRef]

95. Mosnier, L.O.; Gale, A.J.; Yegneswaran, S.; Griffin, J.H. Activated protein C variants with normal cytoprotective but reduced anticoagulant activity. Blood 2004, 104, 1740-1744. [CrossRef]

96. Yang, L.; Bae, J.S.; Manithody, C.; Rezaie, A.R. Identification of a specific exosite on activated protein C for interaction with protease-activated receptor 1. J. Biol. Chem. 2007, 282, 25493-25500. [CrossRef]

97. Mosnier, L.O.; Yang, X.V.; Griffin, J.H. Activated protein C mutant with minimal anticoagulant activity, normal cytoprotective activity, and preservation of thrombin activable fibrinolysis inhibitor-dependent cytoprotective functions. J. Biol. Chem. 2007, 282, 33022-33033. [CrossRef]

98. Bae, J.S.; Yang, L.; Manithody, C.; Rezaie, A.R. Engineering a disulfide bond to stabilize the calcium-binding loop of activated protein $\mathrm{C}$ eliminates its anticoagulant but not its protective signaling properties. J. Biol. Chem. 2007, 282, 9251-9259. [CrossRef]

99. Sarangi, P.P.; Lee, H.W.; Kim, M. Activated protein C action in inflammation. Br. J. Haematol. 2010, 148, 817-833. [CrossRef]

100. Guo, H.; Singh, I.; Wang, Y.; Deane, R.; Barrett, T.; Fernandez, J.A.; Chow, N.; Griffin, J.H.; Zlokovic, B.V. Neuroprotective activities of activated protein $\mathrm{C}$ mutant with reduced anticoagulant activity. Eur. J. Neurosci. 2009, 29, 1119-1130. [CrossRef]

101. Wang, Y.; Thiyagarajan, M.; Chow, N.; Singh, I.; Guo, H.; Davis, T.P.; Zlokovic, B.V. Differential neuroprotection and risk for bleeding from activated protein $\mathrm{C}$ with varying degrees of anticoagulant activity. Stroke 2009, 40, 1864-1869. [CrossRef]

102. Williams, P.D.; Zlokovic, B.V.; Griffin, J.H.; Pryor, K.E.; Davis, T.P. Preclinical safety and pharmacokinetic profile of 3K3A-APC, a novel, modified activated protein $C$ for ischemic stroke. Curr. Pharm. Des. 2012, 18, 4215-4222. [CrossRef]

103. Andreou, A.P.; Efthymiou, M.; Yu, Y.; Watts, H.R.; Noormohamed, F.H.; Ma, D.; Lane, D.A.; Crawley, J.T. Protective effects of non-anticoagulant activated protein C variant (D36A/L38D/A39V) in a murine model of ischaemic stroke. PLoS ONE 2015, 10, e0122410. [CrossRef]

104. Wang, Y.; Zhao, Z.; Chow, N.; Ali, T.; Griffin, J.H.; Zlokovic, B.V. Activated protein C analog promotes neurogenesis and improves neurological outcome after focal ischemic stroke in mice via protease activated receptor 1. Brain Res. 2013, 1507, 97-104. [CrossRef]

105. Wang, Y.; Sinha, R.K.; Mosnier, L.O.; Griffin, J.H.; Zlokovic, B.V. Neurotoxicity of the anticoagulant-selective E149A-activated protein C variant after focal ischemic stroke in mice. Blood Cells Mol. Dis. 2013, 51, 104-108. [CrossRef]

106. Walker, C.T.; Marky, A.H.; Petraglia, A.L.; Ali, T.; Chow, N.; Zlokovic, B.V. Activated protein C analog with reduced anticoagulant activity improves functional recovery and reduces bleeding risk following controlled cortical impact. Brain Res. 2010, 1347, 125-131. [CrossRef]

107. Zhong, Z.; Ilieva, H.; Hallagan, L.; Bell, R.; Singh, I.; Paquette, N.; Thiyagarajan, M.; Deane, R.; Fernandez, J.A.; Lane, S.; et al. Activated protein C therapy slows ALS-like disease in mice by transcriptionally inhibiting SOD1 in motor neurons and microglia cells. J. Clin. Invest. 2009, 119, 3437-3449. [CrossRef]

108. Kerschen, E.J.; Fernandez, J.A.; Cooley, B.C.; Yang, X.V.; Sood, R.; Mosnier, L.O.; Castellino, F.J.; Mackman, N.; Griffin, J.H.; Weiler, H. Endotoxemia and sepsis mortality reduction by non-anticoagulant activated protein C. J. Exp. Med. 2007, 204, 2439-2448. [CrossRef] 
109. Kerschen, E.; Hernandez, I.; Zogg, M.; Jia, S.; Hessner, M.J.; Fernandez, J.A.; Griffin, J.H.; Huettner, C.S.; Castellino, F.J.; Weiler, H. Activated protein C targets CD8+ dendritic cells to reduce the mortality of endotoxemia in mice. J. Clin. Invest. 2010, 120, 3167-3178. [CrossRef]

110. Mosnier, L.O.; Zampolli, A.; Kerschen, E.J.; Schuepbach, R.A.; Banerjee, Y.; Fernandez, J.A.; Yang, X.V.; Riewald, M.; Weiler, H.; Ruggeri, Z.M.; et al. Hyperantithrombotic, noncytoprotective Glu149Ala-activated protein C mutant. Blood 2009, 113, 5970-5978. [CrossRef]

111. Wang, J.; Yang, L.; Rezaie, A.R.; Li, J. Activated protein C protects against myocardial ischemic/reperfusion injury through AMP-activated protein kinase signaling. J. Thromb. Haemost. 2011, 9, 1308-1317. [CrossRef]

112. Costa, R.A.; Wang, J.; Manithody, C.; Li, J.; Rezaie, A.R. Activated protein C modulates cardiac metabolism and augments autophagy in the ischemic heart. J. Thromb. Haemost. 2012, 10, 1736-1744. [CrossRef] [PubMed]

113. Matsuda, A.; Kuriyama, N.; Kato, H.; Tanemura, A.; Murata, Y.; Azumi, Y.; Kishiwada, M.; Mizuno, S.; Usui, M.; Sakurai, H.; et al. Comparative Study on the Cytoprotective Effects of Activated Protein C Treatment in Nonsteatotic and Steatotic Livers under Ischemia-Reperfusion Injury. Biomed. Res. Int. 2015, 2015, 635041. [CrossRef] [PubMed]

114. Bir, N.; Lafargue, M.; Howard, M.; Goolaerts, A.; Roux, J.; Carles, M.; Cohen, M.J.; Iles, K.E.; Fernandez, J.A.; Griffin, J.H.; et al. Cytoprotective-selective activated protein $\mathrm{C}$ attenuates Pseudomonas aeruginosa-induced lung injury in mice. Am. J. Respir. Cell Mol. Biol. 2011, 45, 632-641. [CrossRef] [PubMed]

115. Ni Ainle, F.; O’Donnell, J.S.; Johnson, J.A.; Brown, L.; Gleeson, E.M.; Smith, O.P.; Preston, R.J. Activated protein C N-linked glycans modulate cytoprotective signaling function on endothelial cells. J. Biol. Chem. 2011, 286, 1323-1330. [CrossRef]

116. Lyden, P.; Levy, H.; Weymer, S.; Pryor, K.; Kramer, W.; Griffin, J.H.; Davis, T.P.; Zlokovic, B. Phase 1 safety, tolerability and pharmacokinetics of 3K3A-APC in healthy adult volunteers. Curr. Pharm. Des. 2013, 19, 7479-7485. [CrossRef] [PubMed]

117. Pryor, K.E. ZZ Biotech Announces Preliminary Phase 2 Stroke Trial Results with 3K3A-APC. 2018 [29/01/2018 02/03/2018]. Available online: http://www.b3cnewswire.com/201801291715/zz-biotechannounces-preliminary-phase-2-stroke-trial-results-with-3k3a-apc.html (accessed on 24 January 2019).

(c) 2019 by the authors. Licensee MDPI, Basel, Switzerland. This article is an open access article distributed under the terms and conditions of the Creative Commons Attribution (CC BY) license (http:/ / creativecommons.org/licenses/by/4.0/). 